\title{
NEGLECTED COXITIS TUBERCULOSA MANAGEMENT IN CHILDREN
}

\author{
Sulis Bayusentono ${ }^{1}$, Erwin Ramawan ${ }^{1}$, Henry Dominica ${ }^{2 *}$ \\ ${ }^{1}$ Staff of Orthopaedic and Traumatology Department, Faculty of Medicine, Universitas \\ Airlangga, Dr Soetomo General Hospital, Surabaya \\ ${ }^{2}$ Resident of Orthopaedic and Traumatology Department, Faculty of Medicine, Universitas \\ Airlangga, Dr Soetomo General Hospital, Surabaya \\ *Corresponding Author: Henry Dominica, Resident of Orthopaedic and Traumatology \\ Department, Faculty of Medicine, Universitas Airlangga, Jl. Mayjen Prof. Dr. Moestopo 6-8, \\ Surabaya \\ E-mail: henrydominica@gmail.com
}

\begin{abstract}
ABSTRAK
Latar Belakang: Tuberkulosis masih merupakan salah satu masalah kesehatan serius di seluruh dunia termasuk di Indonesia. Insiden tuberkulosis terus meningkat setiap tahunnya, terutama kasus tuberkulosis tulang yang merupakan bagian dari tuberkulosis ekstra pulmonal sebanyak $10-20 \%$.
\end{abstract}

Kasus: Laporan kasus terhadap pasien perempuan, 2 tahun, dengan neglected posterior hip dextra et causa coxitis TB dextra di RSUD Dr. Soetomo Surabaya, periode Oktober 2013 September 2015. Data diambil secara restropektif dari rekam medis melalui anamnesis, pemeriksaan fisik, pemeriksaan radiologis, dan laboratorium.

Diskusi: Seorang anak perempuan berumur 2 tahun didiagnosa sebagai Neglected Posterior Hip Dextra et causa Coxitis TB Dextra, dilakukan open biopsi, debridement, dan open reposisi melalui pendekatan Anterior Smith Peterson. Dilakukan pemasangan Kirschner wires dan fiksasi eksternal dengan hemispica. Diberikan obat anti-tuberkulosis selama 12 bulan. Dalam pemantauan selama 2 tahun pascaoperasi, pasien dilaporkan mengalami perbaikan.

Kesimpulan: tuberkulosis panggul memiliki variasi manifestasi yang mirip dengan penyakit lainnya. Biopsi dari jaringan lesi tulang merupakan gold standard diagnosis coxitis TB terutama di daerah endemis. Namun interpretasi awal dari gambaran radiologi panggul dapat menjadi prediksi outcome pada kasus coxitis TB.

Kata kunci: tuberculosis panggul, biopsi jaringan, pendekatan Anterior Smith Peterson

\begin{abstract}
Background: Tuberculosis is one of serious health problems throughout the world, including in Indonesia. The incidence of tuberculosis continue to increase annually, especially the case of bone tuberculosis which is part of tuberculosis extra pulmonary as much as $10-20 \%$.

Case: A case report of 2 years old girl, with a neglected posterior hip dextra et causa coxitis tuberculosa dextra in Dr. Soetomo General Hospital, in period October 2013 until September 2015. Data were taken from the retrospective medical record through the anamnesis, physical findings, radiological, and laboratory examinations.

Discussion: A 2 years old girl diagnosed as Neglected Posterior Hip dextra et causa Coxitis TB dextra, carried out of open biopsy, debridement, and open repositioning through the anterior approach Smith Peterson. Do installation of K-Wires and external fixation with hemispica. Given anti-tuberculosis drug for 12 months. In the monitoring for 2 years post-operatively, the patient reported an improvement.

Conclusion: Hip Tuberculosis have a variety of mànifestasi similar to other diseases. Biopsy of the bone tissue lesions is a gold standard diagnosis for coxitis TB. However interpretation of the early picture of pelvic radiology can be a predictor outcome in the case of coxitis TB.

Keywords: tuberculosis pelvis, tissue biopsy, anterior approach smith peterson
\end{abstract}




\section{PENDAHULUAN}

Tuberkulosis merupakan masalah kesehatan di seluruh dunia dengan 8,8 juta penduduk yang mengidap TB. Berdasarkan laporan terakhir WHO, maka TB masuk dalam peringkat kedua sebagai penyebab kematian pada kasus penyakit infeksi setelah HIV. Pada tahun 2011 dilaporkan angka kejadian kasus TB sekitar $59 \%$ di Asia dan $26 \%$ di Afrika. Sedangkan India memiliki angka kejadian kasus baru TB sebesar 2 sampai dengan 2.5 juta kasus. ${ }^{1}$

Angka kejadian kasus tuberkulosis terus meningkat, terutama TB osteoartikular yang merupakan salah satu TB ekstra pulmonal dengan angka kejadian sekitar 10$20 \%$. Infeksi tuberkulosis yang menyerang organ tulang melalui penyebaran infeksi secara hematogen memiliki prevalensi bervariasi tergantung lokasinya. Menurut penelitian meta-analisis yg dilakukan Kulchavenya disebutkan bahwa prevalensi TB pada tulang dan sendi meliputi $11,3 \%$ di USA, 34,5 \% di Rusia, dan $20 \%$ di Nepal dari seluruh kasus TB di masing-masing negara. $^{2}$

Sulitnya deteksi penyakit TB osteoartikular dapat menyebabkan destruksi tulang dan kolaps pada sendi panggul sehingga dapat menimbulkan kecacatan. Oleh karena itu perlu dilakukan upaya deteksi dan tatalaksana sesegera mungkin untuk mencegah komplikasi yang dapat timbul. ${ }^{1}$ Namun, dalam praktek sehari-hari, deteksi dini kasus ini masih sulit dilakukan secara langsung akibat terbatasnya fasilitas diagnostik yang digunakan sehingga seringkali terjadi keterlambatan dalam menegakkan diagnosa dan melakukan tatalaksana. Selain itu misdiagnosis dan tata laksana yang salah masih sering terjadi khususnya di daerah endemis karena TB memiliki manifestasi klinis yang mirip dengan penyakit lainnya. ${ }^{3}$ Keadaan ini juga diperburuk dengan kurangnya pengetahuan masyarakat mengenai kasus ini, sehingga seringkali kasus coxitis ditemukan pada stadium lanjut.

Laporan kasus ini bertujuan untuk mengetahui penegakan diagnosis dan tatalaksana Coxitis TB pada anak. Dengan demikian, diharapkan dapat membantu pemahaman dalam manajemen kasus Coxitis TB.

\section{LAPORAN KASUS}

Seorang anak perempuan berusia 2 tahun dengan keluhan utama tidak bisa berjalan sejak 7 bulan sebelum masuk rumah sakit. Benjolan di lipat paha sebelah kanan, bengkak, tampak kemerahan sekitar benjolan, nyeri sendi panggul saat digerakan sejak 6 bulan SMRS. Nyeri bersifat tajam, 
hilang timbul, intensitas nyeri bertambah setelah terjatuh, nyeri tidak menjalar. Pemeriksaan fisik status generalis dalam batas normal. Status lokalis regio hip dextra berada dalam posisi rotasi internal dan fleksi, tampak shortening deformity, tanda Galeazzi positif (Gambar 1).

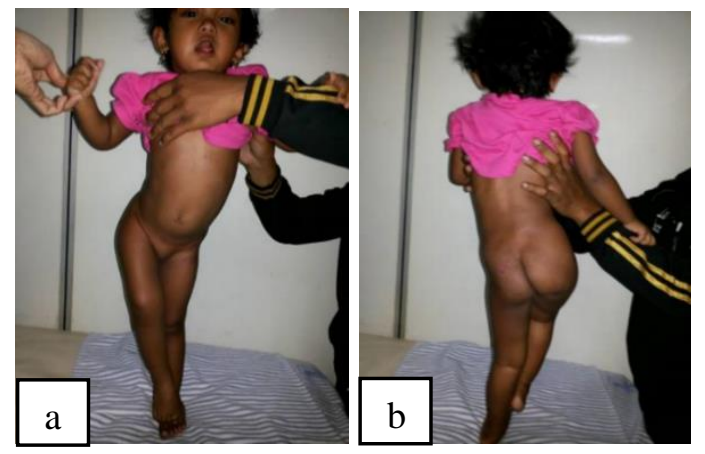

Gambar 1. Foto klinis pasien. Dari depan (a) maupun belakang (b), tampak adanya rotasi internal dan fleksi disertai shortening deformity pada hip kanan.

Teraba massa pada regio hip posterior, konsistensi padat kenyal, bentuk bulat, batas tegas, diameter $3 \mathrm{~cm}$, mobile, nyeri tekan positif. Dari pengukuran Leg Length Discrepancy, didapatkan perbedaan sebesar $2 \mathrm{~cm}$ antara ekstremitas kanan dan kiri. Pengukuran Bryant Triangle antara sendi panggul kanan dan kiri tidak sesuai. Range of Motion (RAM) hip dekstra terbatas.

Gambaran rontgen terdapat gambaran lisis pada caput femur dekstra. (Gambar 2). Hasil laboratorium didapatkan leukositosis dan limfositosis. Pasien terdiagnosis sebagai Neglected Posterior Hip Dextra et causa Coxitis TB Dextra.
Pasien kemudian dilakukan imobilisasi dengan skin traksi, dan dilakukan tindakan open biopsi, debridement untuk membuang pus dan jaringan caseosa caput femoral dan jaringan kartilago, open reposisi dan fiksasi dengan K-wires (Gambar 3).

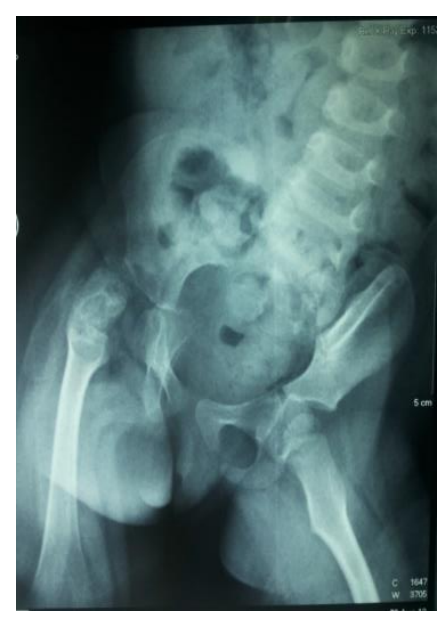

Gambar 1. Foto Rongten Pelvis AP initial nampak bone destruction pada metafisis os femur kanan, subluksasi caput femur kanan terhadap fossa acetabulum, trabekulasi tulang diluar lesi normal, celah dan permukaan sendi masih tampak baik, tak tampak jelas soft tissue swelling.

\section{Teknik Operasi}

Incise yang digunakan adalah anterior approach (Smith-Petersen). Superficial intermuscular plane melalui otot Sartorius dan Tensor fascia lata. Profundal intermuscular plane melalui otot Rectus femoris dan Gluteus medius. Setelah kapsul sendi terlihat, tungkai di-posisikan adduksi dan eksternal rotasi, kemudian dilakukan incise pada kapsul sendi. Setelah incise kapsul, didapatkan destruksi dari permukaan 
kartilago kaput femur dan acetabulum disertai jaringan kaseosa. Tidak didapatkan adanya pus. Tampak subluksasi dari hip joint. Kemudian dilakukan biopsi dari jaringan pada kaput femur, dilanjutkan debridement synovectomy, dan irigasi dengan normal saline. Pada jaringan kapsul yang menebal dilakukan excise. Pasca debridement, dilakukan reposisi dari kaput femur dan fiksasi dengan K-wire untuk mempertahankan stabilitas sendi. Dilakukan penjahitan luka operasi lapis demi lapis tanpa drainage. Pasca operasi dilanjutkan pemasangan hemispica cast dan pemberian Obat Anti-Tuberculosis (OAT).

Hasil pemeriksaan Patologi Anatomi jaringan kaput femur dekstra didapatkan adanya radang granulomatous tuberkulosa dengan Bacill Tahan Asam (BTA) positif.

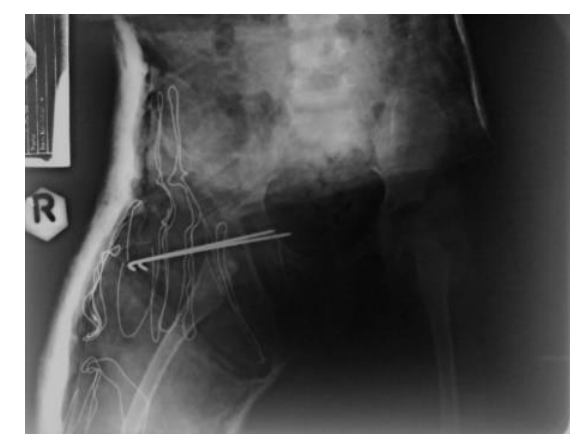

Gambar 3. Foto Rongtent Pelvis AP pascaoperasi. Dilakukan fiksasi dengan $K$ Wires dan dipasang penyangga eksternal dengan hemispica.

Dari hasil kontrol poli rawat jalan, dilakukan pencabutan fiksasi K-wire 6 minggu pascaoperasi. Gips hemispica diganti secara berkala saat kontrol disertai perawatan luka pascaoperasi. Dilakukan pelepasan hemispica 16 minggu pascaoperasi. Post pelepasan hemispica, pasien mulai mobilisasi berjalan. Hasil foto rongten menunjukkan adanya perbaikan. (Gambar 4).

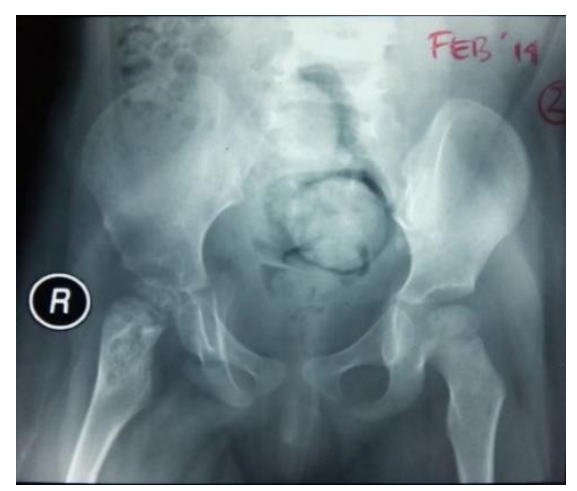

Gambar 4. Foto Rongtent Pelvis AP post pelepasan hemispica (13/02/2014). Masih tampak gambaran bone destruction pada metafisis os femur kanan. Masih tampak destruksi pada acetabulum kanan (dengan gambaran tepi yang mulai kabur). Tampak subluksasi caput femoris kanan dengan fossa acetabulum yang mulai membaik. Trabekulasi tulang diluar lesi normal. Celah dan permukaan sendi masih tampak baik. Tidak tampak soft tissue swelling.

Pada bulan Oktober 2014 pasien selesai menjalani pengobatan TB. Telah dilakukan pemeriksaan pada X-Ray Thorax pada bulan kontrol sebelumnya dan tidak didapatkan adanya kelainan (Gambar 5). Hasil kontrol poli 3 bulan pasca lepas pengobatan TB menunjukkan perbaikan klinis yang bermakna. Pasien telah dapat menggerakkan sendi panggul sisi sebelah kanan secara bebas tanpa disertai rasa nyeri. Dari hasil pemeriksaan X-Ray, tidak didapatkan lagi adanya destruksi maupun 
http://journal.unair.ac.id/ORTHO@journal-orthopaedi-and-traumatology-surabaya-media-104.html

subluksasi sendi (Gambar 6). Hasil pemeriksaan laboratorium didapatkan hasil neutropenia $\quad(2,85 / 36,7 \%) \quad$ dan hipereosinofilia $(0,152 / 196 \%)$, sedangkan jumlah leukosit masih dalam batas nomal. Nilai laboratorium lainnya dalam batas normal.

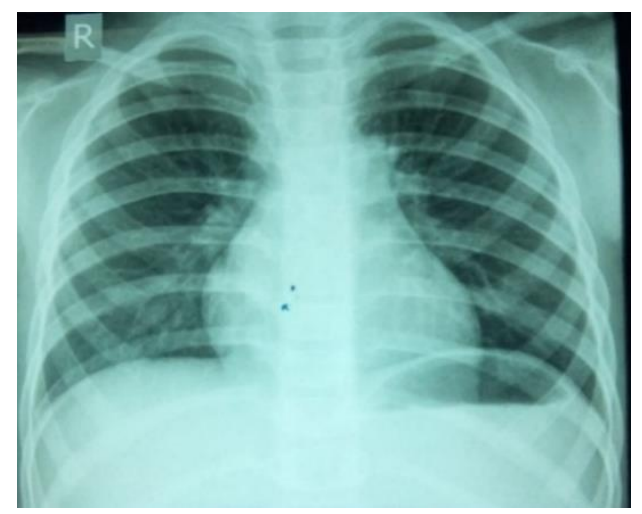

Gambar 2. Foto Rongten Thorax AP (25 Agustus 2014). Gambaran cor dan pulmo dalam batas normal. Tak tampak adanya proses spesifik.

Hasil pemantauan klinis terakhir (24 bulan pascaoperasi) seperti pada Gambar 7 didapatkan pasien telah mampu berjalan dan beraktivitas secara normal. Tidak didapatkan adanya tanda-tanda peradangan pada regio hip dekstra. Tampak luka bekas operasi pada regio inguinal dan hip dekstra. Leg Length Discrepancy dalam batas normal. ROM hip dekstra bebas.

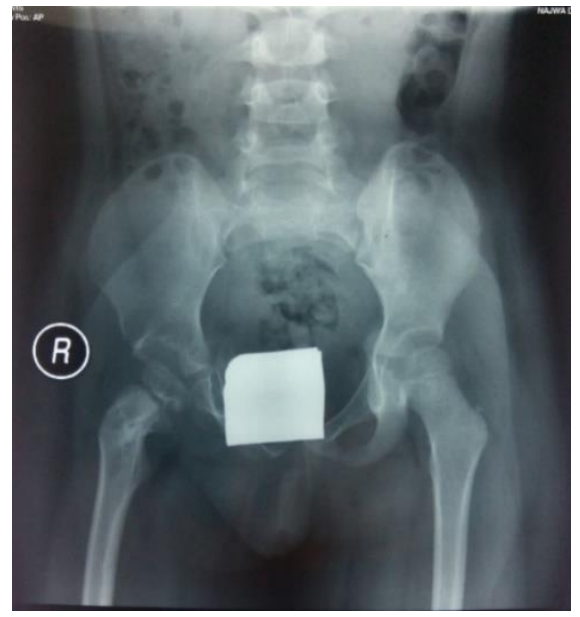

Gambar 3. Foto Rontgen Pelvis AP (7 Januari 2015). Tampak area destruksi pada metafisis sudah mulai mengecil, Sudah tidak didapatkan lagi gambaran subluksasi Caput femoris kanan dengan fossa acetabulum, Sudah tidak didapatkan gambaran destruksi pada acetabulum, Trabekulasi tulang diluar lesi normal.
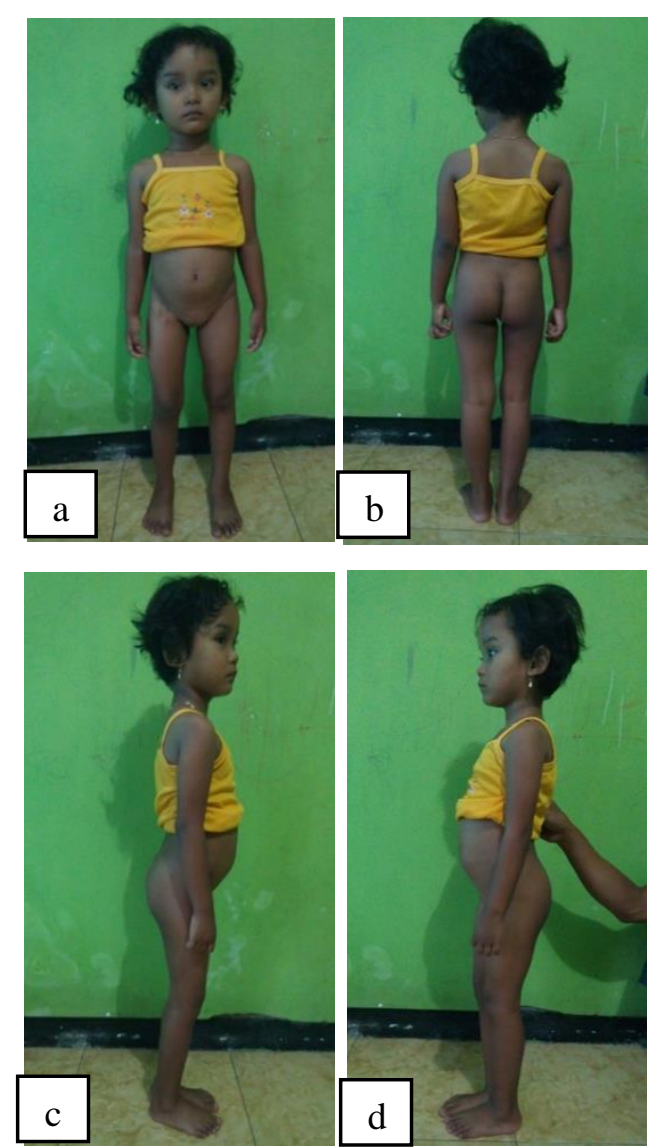

Gambar 7. Foto klinis pasien (11/06/2015) 
Resume pasien dapat dilihat pada Gambar 8 berikut:

\section{RESUME PASIEN}

\begin{tabular}{|c|c|}
\hline $\begin{array}{l}\text { DATANG PERTAMA KALI } \\
\text { Keluhan : tidak bisa berjalan } \\
\text { nyeri pada paha sebelah kanan, bertambah } \\
\text { berat saat malam, bengkak \& kemerahan } \\
\text { di daerah lipat paha kanan }\end{array}$ & $\begin{array}{l}\text { Pemeriksaan Fisik } \\
\text { - hip : rotasi internal dan fleksi, Shortening } \\
\text { deformity, tanda Galeazzi (+), LLD } 2 \mathrm{~cm} \\
\text { - massa pada region hip posterior, ikut bergerak } \\
\text { ketika kaki digerakkan. Massa tersebut terasa } \\
\text { nyeri, Bryant Triangle : ketidak-sesuaian sendi } \\
\text { panggul kanan dan kiri, ROM hip dekstra : } \\
\text { keterbatasan gerak }\end{array}$ \\
\hline $\begin{array}{l}\text { Dx. } \\
\text { Neglected Posterior Hip Dextra et causa } \\
\text { Coxitis TB Dextra }\end{array}$ & \multirow{2}{*}{$\begin{array}{l}\text { Laboratorium } \\
\text { - leukositosis }(17,0 \times 10 \mathrm{e} 3 / \mathrm{uL}) \\
\text { - limfositosis }(9,71 / 57,2 \%) \\
\text { - SGOT mrningkat < } 3 \mathrm{x} \text { normal }(51 \mathrm{U} / \mathrm{L}) \\
\text { - LDH meningkat }(774) \text {. } \\
\text { - Nilai laboratorium lainnya dalam batas normal. }\end{array}$} \\
\hline & \\
\hline $\begin{array}{l}\text { Operasi (Oktober 2013) } \\
\text { open biopsi, debridement, dan open } \\
\text { reposisi, fiksasi dengan K-wires }\end{array}$ & $\begin{array}{l}\text { Foto X-ray } \\
\text { Bone destruction, subluksasi caput femur kanan, } \\
\text { trabekulasi tulang diluar lesi normal, celah dan } \\
\text { permukaan sendi masih tampak baik, tak tampak } \\
\text { jelas soft tissue swelling. }\end{array}$ \\
\hline$\frac{\text { Kontrol } 6 \text { minggu pascaoperasi }}{\text { pencabutan fiksasi K-wire }}$ & \multirow{2}{*}{$\begin{array}{l}\text { Pascaoperasi } \\
\text { - Pemasangan hemispica } \\
\text { - Pemeriksaan Patologi Anatomi (bahan kaput } \\
\text { femur dekstra). Hasil : radang granulomatous } \\
\text { tuberkulosa dengan BTA (Bacill Tahan Asam) } \\
\text { positif } \\
\text { - OAT : RHZE (2 bulan) + RH (10 bulan) }\end{array}$} \\
\hline & \\
\hline
\end{tabular}

Kontrol 16 minggu pascaoperasi pencabutan fiksasi K-wire

\section{Kontrol 12 bulan pascaoperasi \\ Pengobatan OAT selesai. \\ X-Ray Thorax normal.}

\begin{tabular}{c} 
Kontrol 15 bulan pascaoperasi \\
$\begin{array}{c}\text { Perbaikan klinis (ROM bebas, tanpa } \\
\text { nyeri), X-ray : destruksi / subluksasi } \\
\text { sendi negatif }\end{array}$ \\
\hline $\begin{array}{c}\text { Kontrol 24 bulan pascaoperasi } \\
\text { Berjalan \& aktivitas normal } \\
\text { LLD (-), ROM bebas }\end{array}$ \\
\hline
\end{tabular}

Gambar 8. Resume perjalanan penyakit pasien mulai dari awal datang ke Rumah Sakit hingga penyakit membaik 


\section{DISKUSI}

Coxitis TB merupakan salah satu TB osteoartikular pada articulatio coxae akibat penyebaran oleh kuman Mycobacterium Tuberculosis dari suatu fokus infeksi primer di paru. (Gambar 9). Pada umumnya bersifat unilateral atau hanya mengenai satu sendi coxae. Pada pasien yang terkena pada kedua sendi, seringkali terjadi pada saat yang bersamaan. ${ }^{4}$

Paru merupakan port d'entree lebih dari 98\% kasus infeksi TB. Meskipun tidak didapatkan adanya kelainan pada pemeriksaan fisik paru, tidak menutup kemungkinan terjadinya infeksi TB mengingat kuman TB memiliki kecenderungan bersarang di organ yang mempunyai vaskularisasi baik, paling sering di apeks paru. Pada umumnya, kuman di sarang tersebut tetap hidup, tetapi tidak aktif (tenang), dikenal sebagai fokus Simon, yang dikemudian hari dapat mengalami reaktivasi dan terjadi TB apeks paru saat dewasa. ${ }^{5}$ (Gambar 9).

Dari fokus tersebut, kemudian dapat menyebar secara limfogen maupun hematogen ke seluruh tubuh, yang pada kasus ini menyebar ke tulang dan sendi panggul. Penyebaran hematogen yang paling sering terjadi adalah dalam bentuk penyebaran hematogenik tersamar (occult hematogenic spread). ${ }^{5}$ Melalui cara ini, kuman TB menyebar secara sporadik dan sedikit demi sedikit sehingga tidak menimbulkan gejala klinis. Pada kasus ini, gejala baru diketahui setelah anak mengalami trauma dan timbul manifestasi gangguan pada sendi panggul.

Melalui penyebaran hematogen, bakteri akan mencapai synovium dan tulang. Ketika mencapai synovium, akan menyebabkan membran sinovial menjadi oedem dan kongesti. Jaringan granulasi pada synovium dapat menyebar ke tulang dan menyebabkan necrosis subkondral, sekuestra, dan mungkin dapat menimbulkan kissing lession pada sisi sendi lainnya. ${ }^{6}$

Infeksi pada tulang dapat terjadi baik pada intrakapsuler maupun ekstrakapsuler. ${ }^{5}$ (Gambar 10). Ketika infeksi melibatkan intraartikuler, maka progresivitas penyakit akan dengan cepat menyebar ke seluruh sendi. Infeksi pada ekstraartikuler pun dapat melibatkan sendi. Cold abcess yang biasanya terbentuk dapat menimbulkan perforasi pada kapsul sendi dan meluas ke area di sekitar sendi seperti trigonum femorale, aspek medial, lateral posterior paha, serta fossa ischiorectal. ${ }^{7}$ 


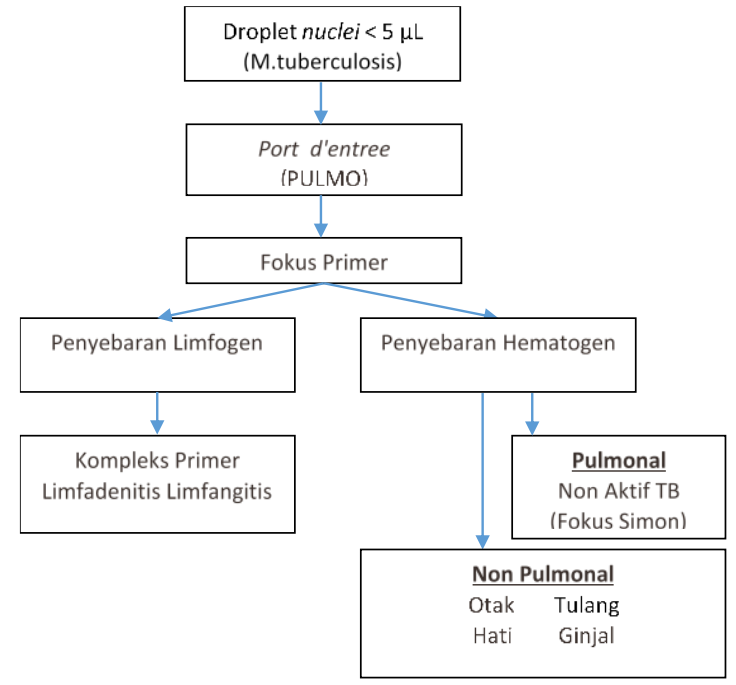

Gambar 9. Bagan pathogenesis penyebaran infeksi $\mathrm{TB}^{5}$

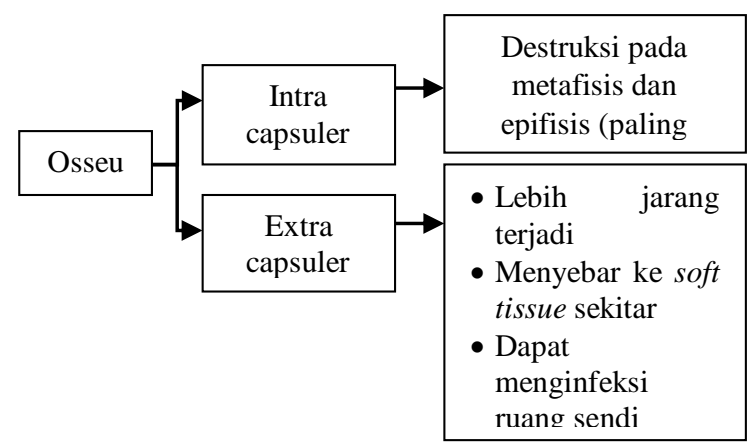

Gambar 10. Bagan pathogenesis coxitis pada region osseus ${ }^{5}$

Pasien biasanya datang dengan presentasi klinis nyeri, gangguan berjalan, dan keterbatasan gerak sendi. Beberapa gangguan sendi hip yang muncul dengan nyeri dan gangguan berjalan seperti transien sinovitis hip, penyakit Legg - Calve Perthes, osteomyelitis proximal femur, injuri pada hip, arthritis akut pada anak, osteoid osteoma pada collum femur dengan keterlibatan sinovial, sinovitis villonodular, rheumatoid arthritis, avascular necrosis caput femur, giant cell tumour proximal femur, dan lain sebagainya. Pemeriksaan penunjang seperti biopsi jaringan mampu membantu menyingkirkan penyebab lain tersebut. ${ }^{8}$

Pemeriksaan penunjang yang dilakukan dalam menegakkan diagnosis pada kasus ini adalah melalui pemeriksaan laboratorium, X-Ray dan pemeriksaan histopatologi. Golden standar pemeriksaan TB adalah dengan pemeriksaan pengecatan BTA (Basil Tahan Asam) / AFB (Acid Fast Bacilli) dengan pewarnaan Ziehl Neelsen, pemeriksaan histopatologi dan PCR (Polymerase Chain Reaction). ${ }^{9}$ Pada kasus ini, didapatkan limfositosis dari pemeriksaan laboratorium, akan tetapi hasil interpretasi tersebut tidak spesifik. Temuan laboratoris pada Coxitis TB secara umum menunjukkan gambaran penyakit kronis seperti anemia ringan, sedangkan jumlah leukosit dapat normal atau meningkat. ${ }^{10}$ Pemeriksaan laju endap darah dan CRP hampir selalu meningkat pada kasus TB, namun pada kasus ini tidak didapatkan data. Hasil ini telah dapat dikonfirmasi dengan pengecatan BTA dengan $\mathrm{ZN}$ pada hasil biopsi.

Dari pemeriksaan radiologis, didapatkan gambaran bone destruction pada metafisis os Femur Dextra, disertai subluksasi caput femoris dextra dengan fossa acetabulum, trabekulasi tulang diluar lesi normal, celah dan permukaan sendi 
masih tampak baik, tak tampak jelas soft tissue swelling. Babhulkar dan Pande memperkenalkan klasifikasi berdasarkan gambaran klinis dan radiologis coxitis TB dan membaginya menjadi 4 stadium (Tabel 1). ${ }^{7,11}$ Menurut klasifikasi tersebut, kasus ini termasuk dalam stadium 3/Arthritis, dengan pertimbangan didapatkan adanya fleksi, adduksi, rotasi internal, pemendekan dari gejala klinis dan terdapat lesi pada caput femoris disertai destruksi pada permukaan artikular. Tuli menyarankan modifikasi klasifikasi tersebut. Sedangkan menurut Tuli (Tabel 2), kasus ini masuk dalam Arthritis Stadium Lanjut.

Menurut Shanmugasundaram, ${ }^{12,13}$ (Gambar 11) tipe kelainan sendi panggul pada pasien ini adalah tipe 3 (dislocating). Pada tipe ini panggul mengalami dislokasi atau subluksasi karena kelenturan kapsul sendi dan hipertrofi sinovial.

Menurut penelitian yang dilakukan oleh Mohideen et al, menyebutkan bahwa gambaran radiologis dari presentasi awal dapat memprediksi outcome dari penyakitnya. ${ }^{14}$ Jika terjadi penyempitan ruang sendi kurang dari atau sama dengan 3 mm, maka prognosisnya kurang baik. ${ }^{8}$ Pada kasus ini celah dan permukaan sendi masih tampak baik, sehingga prognosisnya masih baik.
Tabel 1. Klasifikasi coxitis TB berdasarkan gambaran klinis dan gambaran radiologis (Babhulkar dan Pande) ${ }^{11}$

\begin{tabular}{|l|l|l|}
\hline Stadium & \multicolumn{1}{|c|}{$\begin{array}{c}\text { Gambaran } \\
\text { Klinis }\end{array}$} & \multicolumn{1}{|c|}{$\begin{array}{c}\text { Gambaran } \\
\text { Radiologi }\end{array}$} \\
\hline $\begin{array}{l}\text { Stadium } \\
\text { Sinovitis }\end{array}$ & $\begin{array}{l}\text { Fleksi, abduksi, } \\
\text { rotasi eksternal, } \\
\text { apparent } \\
\text { lengthening }\end{array}$ & $\begin{array}{l}\text { Haziness, } \\
\text { rarefaction }\end{array}$ \\
\hline $\begin{array}{l}\text { Stadium } \\
2\end{array}$ & $\begin{array}{l}\text { Fleksi, aduksi, } \\
\text { Artritis } \\
\text { awal } \\
\text { pemendekan. }\end{array}$ & $\begin{array}{l}\text { Rarefaction, } \\
\text { osteopenia, lesi } \\
\text { tulang pada caput } \\
\text { femur, asetabulum } \\
\text { atau keduanya. } \\
\text { Tidak ada } \\
\text { pengurangan ruang } \\
\text { sendi. }\end{array}$ \\
\hline $\begin{array}{l}\text { Stadium } \\
\text { Artritis }\end{array}$ & $\begin{array}{l}\text { Fleksi, aduksi, } \\
\text { rotasi internal, } \\
\text { pemendekan. }\end{array}$ & $\begin{array}{l}\text { Sesuai dengan } \\
\text { kriteria pada } \\
\text { stadium 2, } \\
\text { terdapat destruksi } \\
\text { pada permukaan } \\
\text { articular, ada } \\
\text { pengurangan ruang }\end{array}$ \\
\hline $\begin{array}{l}\text { Stadium } \\
\text { Artritis }\end{array}$ & $\begin{array}{l}\text { Fleksi, aduksi, } \\
\text { rotasi internal } \\
\text { dengan } \\
\text { pemendekan } \\
\text { yang masif. }\end{array}$ & $\begin{array}{l}\text { Destruksi komplit, } \\
\text { tidak ada ruang } \\
\text { sendi, } \\
\text { penyimpangan } \\
\text { acetabulum. }\end{array}$ \\
\hline
\end{tabular}

Tabel 2. Klasifikasi Tuli tentang perjalanan alamiah TB Arthritis

\begin{tabular}{|c|c|c|c|}
\hline Stadium & $\begin{array}{c}\text { Gambara } \\
\text { n Klinis }\end{array}$ & $\begin{array}{l}\text { Gambaran } \\
\text { Radiologi }\end{array}$ & Terapi \\
\hline Sinovitis & $\begin{array}{l}\text { Pembengk } \\
\text { akan } \\
\text { jaringan } \\
\text { lunak. } \\
75 \% \text { masih } \\
\text { bisa } \\
\text { melakukan } \\
\text { pergerakan } \\
\text { sendi. } \\
\end{array}$ & $\begin{array}{l}\text { Pembeng- } \\
\text { kakan } \\
\text { jaringan } \\
\text { lunak. } \\
\text { Ostopenia. }\end{array}$ & $\begin{array}{l}\text { Kemote-rapi } \\
\text { Istirahat. } \\
\text { ROM. } \\
\text { Gips }\end{array}$ \\
\hline $\begin{array}{l}\text { Artritis } \\
\text { Awal }\end{array}$ & $\begin{array}{l}\text { Pembengk } \\
\text { akan } \\
\text { jaringan } \\
\text { lunak. } \\
\text { Kehilanga } \\
\mathrm{n} \\
\text { pergerakan } \\
\text { sendi } \\
\text { sekitar 25- } \\
50 \% \text {. }\end{array}$ & $\begin{array}{l}\text { Pembengk } \\
\text { akak } \\
\text { jaringan } \\
\text { lunak. } \\
\text { Erosi sendi } \\
\text { marginal } \\
\text { Pengurang } \\
\text { an ruang } \\
\text { sendi. }\end{array}$ & $\begin{array}{l}\text { Kemote-rapi } \\
\text { Istirahat. } \\
\text { ROM. } \\
\text { Gips } \\
\text { Synovec- } \\
\text { tomy }\end{array}$ \\
\hline
\end{tabular}




\begin{tabular}{|c|c|c|c|}
\hline $\begin{array}{l}\text { Artritis } \\
\text { stadium } \\
\text { lanjut }\end{array}$ & $\begin{array}{l}75 \% \\
\text { mengalami } \\
\text { kehilangan } \\
\text { pergerakan } \\
\text { sendi }\end{array}$ & $\begin{array}{l}\text { Erosi } \\
\text { marginal } \\
\text { Kista. } \\
\text { Hilangnya } \\
\text { ruang } \\
\text { sendi } \\
\text { secara } \\
\text { signifikan. }\end{array}$ & $\begin{array}{l}\text { Kemoterapi } \\
\text { Osteotomi } \\
\text { Artrodesis } \\
\text { Artroplasti }\end{array}$ \\
\hline $\begin{array}{l}\text { Artritis } \\
\text { stadium } \\
\text { lanjut } \\
\text { dengan } \\
\text { subluksa } \\
\text { si/disloka } \\
\text { si }\end{array}$ & $\begin{array}{l}75 \% \\
\text { mengalami } \\
\text { kehilangan } \\
\text { pergerakan } \\
\text { sendi. } \\
\text { Subluksasi } \\
\text { atau } \\
\text { dislokasi. }\end{array}$ & $\begin{array}{l}\text { Destruksi } \\
\text { sendi. }\end{array}$ & $\begin{array}{l}\text { Kemoterapi } \\
\text { Osteotomi } \\
\text { Artrodesis } \\
\text { Artroplasti }\end{array}$ \\
\hline
\end{tabular}

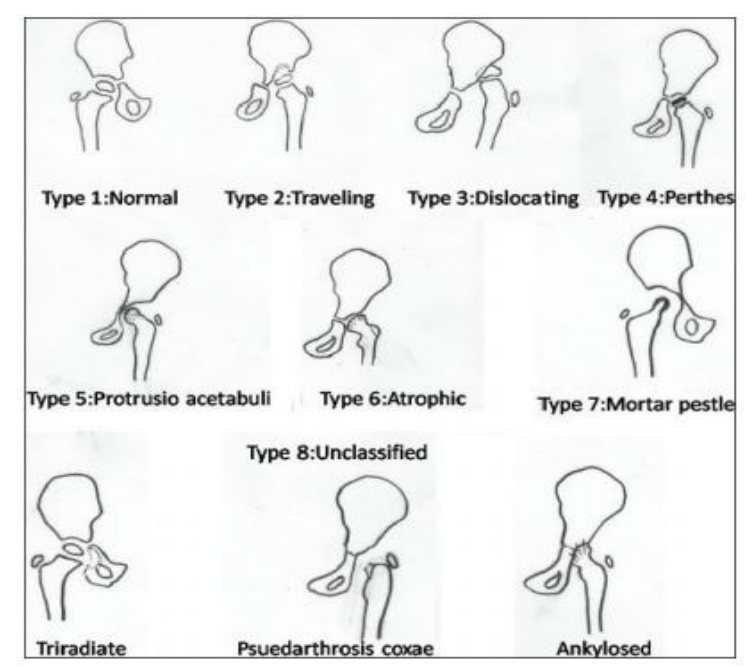

Gambar 11. Diagram kelainan sendi panggul menurut Shanmugasundara. ${ }^{13}$

Terapi pada TB extra-pulmonal memiliki prinsip dasar yang sama dengan terapi pada TB pulmonal. ${ }^{15}$ Obat anti-TB adalah pilar dari manajemen TB extrapulmonal. ${ }^{15,16}$ Menurut Tuli et al (Tabel 2), tatalaksana yang disarankan pada Arthritis Stadium Lanjut meliputi kemoterapi, osteotomi, arthrodesis, arthroplasti. Pada pasien ini dilakukan reposisi terbuka (Anterior Smith-Petersen Approach). Kemudian dilakukan debridemant untuk membuang jaringan kaseosa pada caput femoral dan jaringan kartilago. Lalu dilakukan fiksasi dengan K-wires dan dipasang penyangga eksternal dengan hemispica. Tindakan debridement synovektomi diperlukan pada $30 \%$ kasus yang tidak berespon pada terapi konservatif.

Kelebihan dari approach ini yaitu: ${ }^{17}$

- Diseksi secara superficial maupun profundal dilakukan melalui internervous planes.

- Memudahkan dalam visualisasi dari kolumna anterior dan dinding medial dari acetabulum sehingga dapat memudahkan operator terutama dalam kasus-kasus dislokasi panggul kongenital dan Dysplasia Acetabulum.

- Menghindari terjadinya kerusakan mekanisme abduktor sehingga menghindari komplikasi gangguan berjalan pascaoperasi.

Kekurangan dari approach ini yaitu : ${ }^{17}$

- Operator dapat mengalami kesulitan jika ingin mengidentifikasi kolumna acetabulum dan anal femoral medullary.

- Insisi kulitnya tidak sejenis dengan plane dari intramuscular interval.

Pemberian kemoterapi yang efektif dan diagnosis dini berperan penting dalam menyelamatkan fungsi sendi. ${ }^{6}$ Wang et al menyarankan kombinasi dari terapi OAT selama minimal 2 bulan sebelum operasi dan dilanjutkan dengan minimal 12 bulan setelah operasi. ${ }^{18}$ Prinsip dasar terapi TB pada anak yang disarankan Depkes - IDAI adalah minimal 3 jenis obat (Rifampizin, Pirazinamid, Isoniazid) dalam jangka waktu relatif lama (6-12 bulan), meliputi fase intensif (2 bulan pertama) dan sisanya 
sebagai fase lanjutan. ${ }^{19}$ Pada kasus TB ekstrapulmonal, fase intensif diberikan Rifampisin, Isoniazid, Pirazinamid, dan Ethambutol atau Streptomycine, sedangkan fase lanjutan hanya diberikan Rifampisin dan Isoniazid saja. Pada kasus ini pasien mendapat terapi fase intensif selama 2 bulan dan fase lanjutan selama 10 bulan. Dosis yang diberikan sesuai dengan Tabel 3. Pemberian OAT telah dimulai 2 minggu sebelum operasi dilakukan untuk mencegah penyebaran sistemik.

Tabel 3. Dosis Obat Anti Tuberkulosis (OAT). ${ }^{19}$

\begin{tabular}{|l|c|c|}
\hline Nama Obat & $\begin{array}{c}\text { Dosis harian } \\
\text { (mg/kgBB } \\
\text { /hari }\end{array}$ & $\begin{array}{c}\text { Dosis } \\
\text { maksimal } \\
\text { (mg/kgBB/hari }\end{array}$ \\
\hline $\begin{array}{l}\text { Rifampicin } \\
\text { (R) }\end{array}$ & $10-20$ & 600 \\
\hline Isoniazid (H) & $5-15$ & 300 \\
\hline $\begin{array}{l}\text { Pirazinamid } \\
(\mathrm{Z})\end{array}$ & $15-30$ & 2000 \\
\hline $\begin{array}{l}\text { Etambutol } \\
(\mathrm{E})\end{array}$ & $15-20$ & 1250 \\
\hline $\begin{array}{l}\text { Streptomisin } \\
\text { (S) }\end{array}$ & $15-40$ & 1000 \\
\hline
\end{tabular}

Sebagai tambahan dari terapi farmakologis, Moon et al merekomendasikan pemasangan traksi, terutama skeletal traksi pre operatif. ${ }^{6}$ Weight bearing sedini mungkin disarankan segera setelah pasien mampu mentolerir nyeri. ${ }^{8}$

Keberhasilan pengobatan tergantung dari stadium coxitis pada saat terdiagnosa. Campbell dan Hoffman mengobservasi terdapat hubungan antara tipe gambaran lesi radiologi dan keberhasilan tata laksana. ${ }^{20}$
Hasil pengobatan dengan tingkat keberhasilan baik untuk tipe normal dan tipe Perthes, sedangkan traveling acetabulum, dislocation, mortar and pestle type menunjukkan prognosis buruk. Pada kasus ini, pasien tetap memiliki residual deformity sesudah dilakukan penanganan

\section{KESIMPULAN DAN SARAN}

TB coxitis memiliki gejala yang menyerupai infeksi panggul lainnya yang berakibat sulit untuk terdeteksi secara dini sehingga dapat terjadi keterlambatan diagnosa serta melakukan tatalaksana. Diagnosis coxitis TB ditegakkan melalui anamnesis, pemeriksaan fisik dan pemeriksaan penunjang. Golden standard dalam penegakan diagnosis adalah melalui pemeriksaan kultur kuman M.tuberculosis, pengecatan BTA dengan ZH dan PCR. Di negara berkembang seperti negara Indonesia, yang aplikatif digunakan oleh ahli orthopaedi adalah dengan melihat riwayat penyakit, pemeriksaan fisik dan pemeriksaan radiologi. Pemeriksaan laboratorium tidak dapat menunjukkan penyakit secara spesifik dibandingkan radiologis. Lalu, dikonfirmasi dengan pemeriksaan biopsi jaringan atau pengecatan BTA. Tatalaksana coxitis TB meliputi tatalaksana umum, pemberian OAT, dan operatif. OAT diberikan sesuai dosis baik sebelum maupun setelah menjalani operasi. 
Tatalaksana operasi ditujukan sebagai upaya debridemant, biopsi jaringan dan reposisi deformitas yang mungkin ditimbulkan. Tingkat keberhasilan terapi dikaitkan dengan stadium tipe gambaran radiologi coxitis TB.

\section{REFERENSI}

1. Sharma D, Dhiman P, Rajendiran S, Ravikumar N, Krishna MH. Osteoarticular tuberculosis: in search of new biomarkers. Eur Orthop Traumatol. 2015;6(3):195-200.

2. Kulchavenya E. Extrapulmonary tuberculosis: Are statistical reports accurate? Ther Adv Infect Dis. 2014;2(2):61-70.

3. Vijay PG, Joseph M V. Retrospective Analysis of Varied Clinical Presentations and Delayed Diagnosis in Tuberculosis affection of Extremities. $J$ Orthop case reports. 2012;2(3):12-16.

4. Thijn CJP, Steensma JT. Tuberculosis of the Skeleton: Focus on Radiology. Springer Science \& Business Media; 2012.

https://books.google.com/books?hl=en $\& 1 \mathrm{r}=\& \mathrm{id}=$ YA3HBAAAQBAJ $\&$ pgis $=1$. Accessed October 24, 2015.

5. Kementrian Kesehatan RI. Petunjuk Teknis Manajemen TB Anak. Direktorat Jenderal Pengendalian Penyakit dan Penyehatan Lingkungan Kementerian Kesehatan Republik Indonesia; 2013.

6. Moon Y-W, Kim S-S, Moon M-S, Lee S-R, Moon S-I, Moon J-L. Tuberculosis of hip in children: A retrospective analysis. Indian $J$ Orthop. 2012;46(2):191.

7. Tuli SM. Tuberculosis of the Skeletal System (Bones, Joints, Spine and Bursal Sheaths). 4th ed. New Delhi: Jaypee Brothers Medical Publishers Pvt. Ltd; 2010.

8. Saraf SK, Tuli SM. Tuberculosis of hip: A current concept review. J Orthop.
2015;49(1):1-9.

9. Deshmukh A, Deo S, Salgia AK, Agarwal T. A Rare unusual case presentation of the Tuberculosis of the Shoulder Joint. J Orthop Case Reports. 2013;3(4):25-29.

10. Copley LAB, Herring JA. Infections of the Musculoskeletal System. In: Herring JA, ed. Tachdjian's Pediatric Orthopaedics. 5th ed. Philadelphia: Elsevier; 2014:1057-1061.

11. Babhulkar S, Pande S. Tuberculosis of the hip. Clin Orthop Relat Res. 2002;(398):93-99.

12. Shanmugasundaram TK. Tuberculosis of spine. Indian J Tuberc. 1982.

13. Agarwal A, Gupta N, Suri T, et al. Tuberculosis of the hip in children a retrospective analysis of 27 patients. Indian J Orthop. 2014;48(5):463.

14. Mohideen M, Rasool M. Tuberculosis of the hip joint region in children. South Africa Orthop J. 2013;12(1):38-43.

15. Sia IG, Wieland ML. Current concepts in the management of tuberculosis. Mayo Clin Proc. 2011;86(4):348-361.

16. Lee JY. Diagnosis and Treatment of Extrapulmonary Tuberculosis. Tuberc Respir Dis. 2015;3536:47-55.

17. Schwend R. Anterior Drainage of the Septic Hip in Children. In: Wiesel SW, ed. Operative Technique in Orthopaedic Surgery. 4th ed. Philadelphia: Lippincott Williams \& Wilkins; 2012:1511-1516.

18. Wang Y, Wang J, Xu Z, Li Y, Wang H. Total hip arthroplasty for active tuberculosis of the hip. Int Orthop. 2010;34(8):1111-1114.

19. Kelompok Kerja DEPKES RI - IDAI. Diagnosis Dan Tatalaksana Tuberkulosis Anak. Jakarta: DEPKES IDAI; 2008.

20. Campbell JAB, Hoffman EB. Tuberculosis of the hip in children. $J$ Bone Jt Surg - Ser B. 1995;77(2):319326. 